\title{
ROUSSEAU'S SUPERMAJORITARIAN JUSTIFICATION OF MAJORITY RULE*
}

\author{
LA JUSTIFICACIÓN SUPERMAYORITARIA \\ DE LA REGLA DE LA MAYORÍA EN ROUSSEAU
}

Andrea POZAS LOYO**

Resumen:

Una de las características más polémicas de las democracias constitucionales actuales son las limitaciones que han puesto sobre la regla de la mayoría. Jean Jacques Rousseau fue uno de los defensores más importantes de la soberanía popular. Los pasajes donde él parece dar su total respaldo a la regla de la mayoría son bien conocidos. Sostengo que para Rousseau la legitimidad de la regla de la mayoría en cuestiones de creación ordinaria de derecho descansa sobre su carácter limitado. A diferencia de interpretaciones anteriores (p. ej. Waldron 1990, Weirich 1986 y Grofman y Scott L. 1988), mi interpretación ofrece una explicación coherente e integral de los preceptos de Rousseau para diferentes tipos de creación legislativa, y sobre la relación entre ellos. Planteo una crítica a la interpretación que Waldron hace de Rousseau, y ofrezco una interpretación alternativa para discutir la manera en que las ideas de Rousseau pueden impactar nuestro entendimiento de este importante tema.

* Artículo recibido el 23 de abril de 2013 y aceptado para su publicación el 30 de agosto de 2013.

** Investigadora del Instituto de Investigaciones Jurídicas de la UNAM, México,ap1228@gmail.com

PROBLEMA

Anuario de Filosofia y Teoría del Derecho,

Núm. 8, enero-diciembre de 2014, pp. 449-482 
Esta revista forma parte del acervo de la Biblioteca Jurídica Virtual del Instituto de Investigaciones Jurídicas de la UNAM

ANDREA POZAS LOYO

Palabras clave:

Democracia, regla de la mayoría, soberanía, legitimidad, filosofia politica, Rousseau, Jean Jacques.

\begin{abstract}
:
One of the most polemic characteristics of contemporary constitutional democracies is the limit they place on majority rule. Jean Jacques Rousseau is one of the most important advocates of popular sovereignty. The passages where he seems to give full support to majority rule are well known. I argue that for Rousseau the legitimacy of majority rule for ordinary lawmaking rests on its limited character. Unlike previous interpretations (e.g. Waldron 1990, Weirich 1986, and Grofman and Scott L. 1988) my interpretation gives a comprehensive and coherent account of Rousseau's prescriptions for different kinds of law-making, and of the relation among them. I present a criticism of Waldron's influential interpretation of Rousseau, and discuss the way Rousseau's thoughts can further our understanding on this important issue.
\end{abstract}

Keywords:

Democracy, Majority Rule, Popular Sovereigntiy, Legitimacy, Political Philosophy, Rousseau, Jean Jacques. 
Esta revista forma parte del acervo de la Biblioteca Jurídica Virtual del Instituto de Investigaciones Jurídicas de la UNAM www.juridicas.unam.mx

http://biblio.juridicas.unam.mx

SUPERMAJORITARIAN JUSTIFICATION OF MAJORITY RULE

SUMmaRY: I. Introduction. II. How Should We Make Decisions? Rousseau's Qualified Approach. III. Waldron Revisits Rousseau. IV. Conclusion. V. References.

\section{INTRODUCTION}

... [T] he vote of the majority always obligates all the rest; this is a consequence of the contract itself.

Jean Jacques Rousseau, Of the Social Contract IV, ii, 124.

One of the most controversial characteristics of contemporary constitutional democracies is the limit they place on majority rule. Majority rule has often been characterized, although not uncontrovertibly, as the mark of democratic decision-making. ${ }^{1}$ Then, the fact that in contemporary constitutional democracies there are some decisions that cannot be made even in the presence of a majority of the people's representatives supporting them has called into question the "democratic" pedigree of those restrictions, and has raised the question "Is Constitutional Democracy: A Paradoxical Union of Contradictory Principles?", as Habermas nicely phrased it. ${ }^{2}$

Jean Jacques Rousseau is one of the most important advocates of popular sovereignty. The passages where he

1 It is important to note that the claim that majority rule (i.e. $50 \%+1$ of the votes) is a necessary and sufficient condition for a decision to be democratic has had many opponents throughout the history of political thought. Aristotle had already noted: "the principle of the rule of majority-decision is present in all constitutions". Aristotle, Politics, translated by H Rackham, Loeb Classical Library, Cambridge, M. A: Harvard University Press, 1977, p. 152.

2 See: Habermas Jurgen, "Constitutional Democracy: A Paradoxical Union of Contradictory Principles?” Political Theory, vol. 29, num. 6, December, 2001; Holmes Stephen, "Constitutionalism", in Seymour Martin Lipset (ed.), The Encyclopedia of Democracy, Washington, Congressional Quarterly, 1995. 
Esta revista forma parte del acervo de la Biblioteca Jurídica Virtual del Instituto de Investigaciones Jurídicas de la UNAM www.juridicas.unam.mx

http://biblio.juridicas.unam.mx

ANDREA POZAS LOYO

seems to give full support to majority rule are well known. Therefore, it is not surprising that he has been an important reference for authors, like Jeremy Waldron, who support majority rule as the democratic decision-making process against any countermajoritarian protection of rights.

The objective of this paper is to call into question the purely majoritarian interpretation of Rousseau. My thesis is that for Rousseau the legitimacy of majority rule for ordinary lawmaking rests on its limited character. I argue that Rousseau provides a coherent set of prescriptions for political decision-making procedures. I present a framework that unfolds the elements involved in Rousseau's selection of a decision-making mechanism, and show that he only prescribes majority rule for ordinary law under non-ideal circumstances. Unlike previous interpretations (e.g. Waldron 1990, Weirich 1986, and Grofman and Scott L. 1988) my interpretation gives a comprehensive and coherent account of Rousseau's prescriptions for different kinds of law- making, and of the relation among them.

The paper is divided into three parts. In the first one I present and defend my interpretation of Rousseau's normative claims on political decision-making processes. In the second, I present a criticism of Waldron's interpretation of Rousseau. I conclude with a brief discussion on the way Rousseau's ideas provide useful insights into the contemporary debate on decision-making mechanisms in democracies.

\section{How Should We Make Decisions? Rousseau's QUALIFIED APPROACH}

Let us first note that the question "what is the most desirable decision-making procedure for political decisions?" can be approached in at least two different ways. The first one determines a priori some desirable normative principles that guide the choice, and a set of fundamental characteristics of political decisions. The question then becomes which 
Esta revista forma parte del acervo de la Biblioteca Jurídica Virtual del Instituto de Investigaciones Jurídicas de la UNAM www.juridicas.unam.mx

http://biblio.juridicas.unam.mx

SUPERMAJORITARIAN JUSTIFICATION OF MAJORITY RULE

is the decision-making procedure that best complies with the principles, given the characteristics of political decisions. This approach concludes that the answer to such a question should be applied to any political decision in any given circumstance, since it is the one that best complies with the guiding normative principles. So for instance, if majority rule is the decision-making process that best embodies the democratic principles of equality and liberty, it should be used in all decision-making processes.

The second approach considers that the kind of decision to be made and its circumstances are fundamental for determining which decision-making procedure to prescribe and thus a mechanism that is desirable in a given context might be undesirable in another. An important consequence of this second approach is that the best decision-making procedure under ideal circumstances is not necessarily the best under less than ideal conditions.

Rousseau has often been portrayed as a utopian author, not concerned with the feasibility of his political prescriptions but centered in the normative value of his strong political and social criticism and his ideals. ${ }^{3}$ The interpretation of Rousseau that I defend here delivers a non-purely utopian political thinker, but rather an author who is concerned both with ideal institutions and with prescribing institutions under less than ideal conditions. ${ }^{4}$ Here I defend that Rousseau approached the question of the best political decision-making procedure from the second perspective mentioned above. First, let me show that he did not consider that there is a decision-making mechanism that should be applied for all political decisions under any cir-

3 E. g. Skhlar, Judith N., Men and Citizens: A Study of Rousseau's Social Theory, New York, Cambridge University Press, 1985 and Miller, J., Rousseau: Dreamer of Democracy, New Haven, CT, Yale University Press, 1984.

4 For a similar interpretation on a different issue see: Putterman, Ethan, Rousseau, Law and the Sovereignty of the People, Cambridge, Cambridge University Press, 2010. 
Esta revista forma parte del acervo de la Biblioteca Jurídica Virtual del Instituto de Investigaciones Jurídicas de la UNAM www.juridicas.unam.mx

http://biblio.juridicas.unam.mx

ANDREA POZAS LOYO

cumstance since contextual variables are necessary for a correct prescription.

This claim follows from the fact that he considers that a decision-making procedure that is desirable under ideal conditions or for deciding to form a social contract can be highly perverse under less than ideal circumstances and for purposes of amending. His analysis of the Polish libertum veto (unanimity rule in the Polish Diet) makes this point clear. Let me quote at length:

In itself the libertum veto is not a vicious right, but as soon as it passes its bounds it becomes the most dangerous of abuses: it was the guarantee of public liberty; it is no longer anything but the instrument of oppression... Only a patriotism enlighten by experience can learn to sacrifice to greater goods a brilliant right that has become pernicious by its abuse, and from which this abuse is henceforth inseparable...

If they (all the Poles) love order and peace, they have no means for establishing both among them as long as they allow to continue to exist this right [the libertum veto], what is good during the formation of the body politic or when it has all its perfection, but that is absurd and fatal as long as there are changes left to make and it is impossible for there not always be some, above all in a large State surrounded by powerful and ambitious neighbors. ${ }^{5}$

In the Social Contract we find several claims in the same direction. A particularly clear one is: "Just as the regime of the healthy people is not suited to the sick, one must not try to govern a corrupt people by the same Laws as those

5 Rousseau, Jean Jacques, "Considerations on the Government of Poland and on Its Planned Reformation" in Christopher Kelly (ed.) Collected Writings of Rousseau, vol. II, Lebanon, NH, University Press on New England, 2005, pp. 202-203 emphasis added. 
Esta revista forma parte del acervo de la Biblioteca Jurídica Virtual del Instituto de Investigaciones Jurídicas de la UNAM www.juridicas.unam.mx

http://biblio.juridicas.unam.mx

SUPERMAJORITARIAN JUSTIFICATION OF MAJORITY RULE

that suit a healthy good people". ${ }^{6}$ In sum, the variables that Rousseau considers relevant to answer our question preclude the possibility of having a unique answer valid for every possible case. ${ }^{7}$

Now, if Rousseau's normative account on decision-making procedures does not provide a unique answer, it is important not to focus only on a part of his account and then generalize it to all settings and decisions, such a move would constitute a the fallacy of composition. ${ }^{8}$ In order to avoid this problem we need to make explicit the framework that enables us to identify the variables of decision-making contexts that are of importance in deciding which decision-making procedure is suitable in order to have a consistent interpretation of Rousseau's prescriptions. In other words, we need to find the categories that identify the cases where generalizations are grounded. Let me now build such a framework helped by the distinctions we find in Rousseau's texts.

\section{A Framework for Deciding how to Decide}

\section{A. Reasons to Choose a Decision-Making Procedure}

Before describing the specific variables of Rousseau's analyses let us consider the different types of reasons that we find in his texts grounding the choice of a decision-making procedure. There are three kinds of reasons that can do the work: ${ }^{9}$

6 Rousseau, Jean Jacques, "Of the Social Contract" in Gourevitch, Victor (ed. and trans.) The Social Contract and other Later Political Writings, Cambridge, Cambridge University Press, 1997, IV, iv, p. 135.

7 We will later clarify what circumstantial elements are of importance for Rousseau.

8 In the second part of this paper I claim that Waldron's interpretation has this problem.

9 Arguably we can accommodate all reasons in favor of a decision-making mechanism in at least one of these categories. 
Esta revista forma parte del acervo de la Biblioteca Jurídica Virtual del Instituto de Investigaciones Jurídicas de la UNAM www.juridicas.unam.mx

http://biblio.juridicas.unam.mx

ANDREA POZAS LOYO

i) Moral reasons (e.g. considerations of equality, liberty and/or fairness) ${ }^{10}$

ii) Pragmatic reasons (e.g. time constraints)

iii) Epistemic reasons (e.g. consideration of which method is more likely to lead to correct decisions or to enable an efficient way to correct mistakes).

Thus, a thorough analysis of what decision-making procedure is suitable in a given context would take into consideration the moral, pragmatic and epistemic aspects of the decision-making procedure. As we will see these considerations will not always lead to the same choice and, if this is the case, an argument for why one aspect is considered determinant will need to be provided.

Now, note that a decision-making process has three elements on which an argument in its favor can be focused. We can first differentiate between arguments that defend a decision-making procedure based on how it treats the inputs (i.e. the individual votes, preferences or options), and b) the quality its output (i.e. decision). In addition, we can also consider c) other desirable consequences of the process (e.g. it promotes stronger support for the laws).

Now, moral arguments can be focused both on the input and on the output (e.g. "the procedure guarantees equality by weighting the votes equally" or "the procedure blocks certain unfair majoritarian decisions respectively). Epistemic arguments focus on the output (e.g. "the procedure maximizes the probability that the correct decision is taken"), while pragmatic arguments focus on consequences of the procedure other than the quality of the decision itself (e.g. time is saved).

10 For an interesting account on the moral aspect of Rousseau's theory of decision-making procedures see: Schwartzberg Melissa, "Voting the General Will: Rousseau on Decision Rules", Political Theory, vol. 36, num. 3, 2008, pp. 403-423. 
Esta revista forma parte del acervo de la Biblioteca Jurídica Virtual del Instituto de Investigaciones Jurídicas de la UNAM www.juridicas.unam.mx http://biblio.juridicas.unam.mx

SUPERMAJORITARIAN JUSTIFICATION OF MAJORITY RULE

Table 1

\begin{tabular}{|c|c|c|c|}
\hline \multirow{2}{*}{$\begin{array}{c}\text { Type } \\
\text { of argument }\end{array}$} & \multicolumn{3}{|c|}{ Focus of the Argument } \\
\cline { 2 - 4 } & Input & Output & $\begin{array}{c}\text { Other } \\
\text { consequences }\end{array}$ \\
\hline Moral & $\mathrm{X}$ & $\mathrm{X}$ & \\
\hline Epistemic & & $\mathrm{X}$ & $\mathrm{X}$ \\
\hline Pragmatic & & & \\
\hline
\end{tabular}

B. Decision-Making Procedures to Make Laws versus Decision-Making Procedures to Select Governmental Officials

Rousseau distinguishes between decision-making processes to make laws and decision-making processes to choose the government. ${ }^{11}$ But what grounds this distinction? Why can we not assume that the decision-making mechanism that best suits the making of laws also best suits the election of the government (or vice versa)? The answer to this question is that for choosing the government considerations about the selected citizens play a fundamental role, while clearly these considerations do not apply for law making. This of course, does not ex-ante preclude the possibility that we will end up prescribing the same decision-making process for these two kinds of decisions; the point is that if this was the case each prescription would be grounded in different reasons. This argument is suggested in Rousseau's analysis of the best decision-making procedure (election by majority rule or lot) to choose "the prince and magistrates" in democracies, aristocracies, and mixed governments:

In every genuine Democracy, magistracy is not an advantage but a burdensome charge, which one cannot justly impose on one individual...Elections by lot would entail few incon-

11 Rousseau, "Of the Social Contract", cit., IV, iii, p. 125. 
Esta revista forma parte del acervo de la Biblioteca Jurídica Virtual del Instituto de Investigaciones Jurídicas de la UNAM www.juridicas.unam.mx

http://biblio.juridicas.unam.mx

ANDREA POZAS LOYO

veniencies in a genuine Democracy where everything is as equal by virtue of morals and talents as maxims and fortunes...In Aristocracy the Prince chooses the Prince, the Government perpetuates itself by itself, and that is where voting is appropriate... Where election by choice and election by lot are combined [i.e. in mixed governments], choice should fill the positions that require specific talents, such as military offices; drawing lot is appropriate for positions where good sense, justice, integrity suffice, such as judicial responsibilities, because in a well -constituted State these qualities are common to all Citizens. ${ }^{12}$

Note how Rousseau's prescriptions for the selection of governmental officials are grounded on moral considerations (fairness in imposing a burden) and epistemic considerations (need of specific talents) regarding the selected citizens. Given that our focus is decision-making procedures to make laws, we will not pursue further analysis on the best decision-making process to fill public offices; the important point is to note that for Rousseau these decisions constitute a different category. ${ }^{13}$

\section{Considering the Decision-Makers}

Not surprisingly, in Rousseau's analysis moral and epistemic considerations about decision-makers play an important role for determining the most suitable decision-making procedure to make laws. ${ }^{14}$ We will here give account of how Rousseau captures these considerations and in the third part of the paper we will discuss in what way it can illuminate the contemporary debate.

12 Ibidem, pp. 125-126.

13 Arguably this distinction is less clear cut in a representative government where the selected officials vote the laws and thus where the decision-making procedure for representatives is consequential for law-making.

14 Considerations of this kind are present in many of the most important treatments of this issue (e.g. Aristotle, Kelsen, Waldron). 
Esta revista forma parte del acervo de la Biblioteca Jurídica Virtual del Instituto de Investigaciones Jurídicas de la UNAM www.juridicas.unam.mx

http://biblio.juridicas.unam.mx

SUPERMAJORITARIAN JUSTIFICATION OF MAJORITY RULE

The first important point to make is that for Rousseau the epistemological and the moral attributes of decisionmakers are intrinsically linked. Rousseau considers that there is always a "correct" decision: the one required by the general will. 15 So decision-makers are epistemologi- cally capable if they clearly perceive the general will. Now the capacity of clearly perceiving the general will is linked to the moral status of the decision-makers: in a virtuous state the citizens clearly perceive the general will and vote accordingly, while in a society that has started the inevitable moral decay, the perception of the general will is obstructed by private interests (either individual or factionary). Thus, when deciding which decision-making mechanism to prescribe, a fundamental consideration will be the degree of moral decay of the State that signals the epistemic status of the decision-makers. ${ }^{16}$ This point is nicely put in the conclusion of one of Rousseau's arguments.

From these various considerations arise the maxim that should regulate the manner in which votes are counted and opinions compared, taking account of whether the general will

15 See for instance Rousseau, "Of the Social Contract”, cit., II, iii, p. 59.

16 In Rousseau's political writings which concern us here the emphasis is on the collective moral status (i.e. the moral status of the state) which determines the individual one; a perverted political society perverts its citizens by inserting them in relations of dependency since the time they are very young. In contrast, in the Emile Rousseau focuses on the individual and the possibility of individual non-dependency and virtue through education. However, common prescription is evident: "There is some moral order everywhere that there is feeling and intelligence. The difference is that the good person orders himself in relation (par rapport) to the whole, and that the evil person orders the whole in relation to himself. The later makes himself the center of all things; the other measures his radius and holds himself at the circumference". Rousseau Jean Jacques, Émile or on Education, Allan Bloom (trans.), New York, Basic Books, 1979, p. 602. 
is more or less easy to know, and the State more or less in decline. ${ }^{17}$

We can think of Rousseau's moral evaluation of states as a continuum; in one extreme the ideal state and in the other the most corrupt one. We need to understand the way in which considerations about the moral status of states can impact the choice of the most suitable decision-making procedure. For that it is important to note that the degree of agreement -understood as the percentage of equal votes - signals the moral status of the state.

...it is evident that the way in which general business is conducted provides a fairly reliable indication of the current state of the morals and the health of the body politic. The more concord reigns in the assemblies, that is to say the closer opinions come to unanimity, the more the general will also predominates; whereas long debates, dissensions, disturbances, signal the ascendancy of particular interests and the decline of the State. ${ }^{18}$

In the ideal state, the small homogenous agricultural patriotic republic, the common good is easily perceived, decisions are always unanimous and they express the general will.

A State thus governed needs very few Laws, and as it becomes necessary to promulgate new ones, this necessity is

17 Rousseau, "Of the Social Contract", cit., p. 123, emphasis added. Note that therefore, the only way to improve the epistemic competence of decision-makers is to improve the moral status of the State with the guidance of a lawgiver capable of transforming human nature corrupted by the emergence of amour propre. "Do you want the general will to be accomplished? Make all private wills be in conformity with it. And since virtue is merely this conformity of the private to the general will, in a word, make virtue reign". Rousseau, Jean Jacques, "Discourse on Political Economy" in The Basic Political Writings, Donald A. Cress (trans.), Indianapolis, Hackett Publishing Company, 1987, p. 119.

18 Rousseau, "Of the Social Contract", cit., IV, ii, pp. 122-123. 
Esta revista forma parte del acervo de la Biblioteca Jurídica Virtual del Instituto de Investigaciones Jurídicas de la UNAM www.juridicas.unam.mx

http://biblio.juridicas.unam.mx

\author{
SUPERMAJORITARIAN JUSTIFICATION OF MAJORITY RULE
}

universally seen. The first one to propose them only states what all have already sensed, and there is no need for intrigues or eloquence to secure passage into law of what each has already resolved to do as soon as he is sure that the others will do so as well.19

As soon as disagreements arise, and a suggested bill no longer attracts unanimous approval, we can be sure that the moral status of the state has changed; private interest (individual or factionary) has taken precedence over the general will in the decisions of a set of the decision-makers.

But when the social knot begins to loosen and the State to weaken; when particular interests begin to make themselves felt and small societies to influence the larger society, the common interest diminishes and meets with opposition, votes are no longer unanimous, the general will is no longer the will of all, contradictions and disagreements arise, and the best opinion no longer carries the day unchallenged. ${ }^{20}$

Finally, unanimity returns when we have reached the other extreme: "at the other end of the cycle... That is when the citizens, fallen into servitude, no longer have freedom or will". 21

So the continuum of the moral status of a state and its relation with the expected degree of agreement of votes is the following: In the ideal state the expected degree of agreement (i.e. the expected percentage of equal votes) is $100 \%$. The degree of agreement diminishes as moral decline progresses. So for instance, in a state where a quarter of its citizens have enabled private interests to prevail over the general will, the expected degree of agreement is of at least $75 \%$. Note that in this state we could have decisions approved by more than the $75 \%$ (when the private interests of a fraction or individual happen to coincide with what the

19 Ibidem, IV, i, p. 121.

20 Ibidem, IV, i, pp. 121-122.

21 Ibidem, IV, ii, p. 123. 
Esta revista forma parte del acervo de la Biblioteca Jurídica Virtual del Instituto de Investigaciones Jurídicas de la UNAM www.juridicas.unam.mx

http://biblio.juridicas.unam.mx

ANDREA POZAS LOYO

general will requires), but never by less. This process continues until near the middle point of the continuum we reach a state where "all the characteristics of the general will are still in the majority..."22 and where the expected degree of agreement will be of at least $50 \%+1$. Once we have passed this point, the linear relation between the expected degree of agreement and the level of corruption will be broken; the levels of agreement will depend on the number of factions, their membership and the arbitrary coincidence of their interests regarding the law at hand. The fewer factions there are and the more powerful they are the more corrupt the state will be. ${ }^{23}$ As factions become less numerous and more powerful the expected level of agreement will rise until we reach the lower extreme where the expected agreement is again of $100 \%$.

It is important to note that the degree of agreement is caused by the decision-makers' epistemic status (i.e. that those who agree know the correct answer) only in the first part of the continuum. In the second part, while their epistemic capacity decays, agreement increases but this time it is caused by the convergence of private interests or fear. Let us go over the last elements of the framework.

\section{Kind of Decision}

We find in Rousseau's texts two last distinctions relevant in determining which decision-making mechanism should be chosen. The fist one establishes the importance of the decision while the second points to its urgency. Rousseau categorizes decisions according to their importance, being the most important the original decision of forming a social contract, followed by the fundamental laws of a state, then the matters of legislation, and lastly the norms concerned

22 Ibidem, IV, ii, p. 124.

23 Ibidem, II, iii, p. 60. 
Esta revista forma parte del acervo de la Biblioteca Jurídica Virtual del Instituto de Investigaciones Jurídicas de la UNAM www.juridicas.unam.mx

http://biblio.juridicas.unam.mx

SUPERMAJORITARIAN JUSTIFICATION OF MAJORITY RULE

with administration. ${ }^{24}$ These distinctions and the fact that they play an important role in establishing which decision-making mechanism ought to be chosen is clear in the following quote:

Between the veto which is the greatest individual force that the members of the sovereign power can have and which ought not to take place except for genuinely fundamental laws, and plurality, which is the smallest and which relates to matters of simple administration, there are different propositions upon which one can determine the preponderance of opinions in proportion to the importance of the matter...

For example when it is a question of legislation, one can require at least three-quarters of the suffrages, two-thirds in matters of State, plurality only to elections and other routine and momentary business. ${ }^{25}$

Finally, playing an important role in Rousseau's prescriptions we find the urgency of the question. This practical consideration is vital since the costs of delaying an urgent question by requiring a strong supermajority are very high, as Polish history has shown. We finally have all the elements in place to provide a complete and consistent account of Rousseau's prescriptions for decision-making processes.

\section{What Decision-Making Should Be Used?}

\section{A. The Decision-Making for the Ideal State}

As we have seen, in the ideal state laws conform to the general will and are approved in an expedient way with a unanimous vote independent of the decision-making mech-

24 Note that matters of administration are not law-making for Roseau see: Ibidem, II, vi, p. 67 and "Considerations on the Government of Poland and on Its Planned Reformation”, cit., p. 203.

25 Ibidem, p. 204 emphasis added. 
Esta revista forma parte del acervo de la Biblioteca Jurídica Virtual del Instituto de Investigaciones Jurídicas de la UNAM www.juridicas.unam.mx

http://biblio.juridicas.unam.mx

ANDREA POZAS LOYO

anism that is in place. Therefore, in choosing a decisionmaking mechanism for this state epistemological and pragmatic considerations are not relevant. Just as the problem of distributive justice does not arise in a world without scarcity, ${ }^{26}$ epistemological and pragmatic problems with the decision-making process do not arise in a state where the decisions are always correct and expedient. Hence, only moral considerations are relevant to determining the decision-making mechanism that ought to be established in the ideal state. ${ }^{27}$ Moreover, since in the ideal state laws always conform to the general will they are always moral, so moral considerations focused on the out-put of decisions are also irrelevant to the choice.

Thus, our question in this case is narrowed to: "which is the decision-making procedure that better complies with Rousseau's core moral principles (freedom and equality) in the way it treats the individual's input?". ${ }^{28}$ The answer is clear: unanimity is the only decision-making mechanism that guarantees individual freedom by making each vote necessary for passing a law (i.e. by guaranteeing voluntary subjection to law) while maintaining equality by giving each vote an equal ex-ante weight. Note that unanimity does not guarantee ex-post equal weight since in case of disagree-

26 Hume David, Enquiries Concerning Human Understanding and Concerning the Principles of Morals, Oxford, Clarendon Press, 1975, pp. 183-184 and Rawls John, A Theory of Justice, Cambridge, Harvard University Press, 1999, p. 110.

27 Cfr. Weirich, Paul, "Rousseau on Proportional Majority Rule", Philosophy and Phenomenological Research, vol. XLVII, num. I, September, 1986. Weirich argues that proportional majority is Rousseau's prescription for every state including the ideal one.

28 "If one inquires into precisely what the greatest good of all consists of, which ought to be the end of every system of legislation, one will find that it comes down to these principal objects, freedom and equality. Freedom, because any individual dependence is that much force taken away from the State; equality, because freedom cannot subsist without it, Rousseau, "Of the Social Contract", cit., II, xi, p. 78. 
Esta revista forma parte del acervo de la Biblioteca Jurídica Virtual del Instituto de Investigaciones Jurídicas de la UNAM www.juridicas.unam.mx

http://biblio.juridicas.unam.mx

SUPERMAJORITARIAN JUSTIFICATION OF MAJORITY RULE

ment a vote weighs more than all the rest, but clearly in the ideal state this will not be a problem.

In sum, this interpretation allows us to give account of the fact that Rousseau prescribes unanimity for the body politic "when it has all its perfection", ${ }^{29}$ and to see that unanimity in the ideal state is the only decision-making mechanism that completely realizes Rousseau's core moral principles and satisfies all his epistemic and pragmatic preoccupations.

\section{B. Decision-Making Mechanism for non-Ideal States}

Once we leave the ideal world and disagreement arises, our question becomes more difficult. The first important problem is that we have no clear criterion for identifying the exact point in the continuum of moral decay where our state is. The level of disagreement is not reliable outside persistent unanimity (which as we have said signals the two extremes of the continuum). This is so because -as we discussed-agreement can be due either to the general will or to convergence of private interests. In addition, the level of moral decay of a state is not fixed. Note that without this uncertainty regarding the moral/epistemic status of the decision-makers the question would be much easier; the best decision-making mechanism would be the one that corresponds to the proportion of citizens that still maintains all the characteristics of the general will. This point is clear in Rousseau, his famous epistemic argument for majority rule, which most of the times is quoted without one of its fundamental assumptions. ${ }^{30}$

29 Rousseau, "Considerations on the Government of Poland and on Its Planned Reformation", cit., p. 203; see also Rousseau, "Of the Social Contract", cit., IV, i, p. 121.

30 This assumption is close to the Condorcetian assumption that the probability of any given citizen making the correct decision is $p=.51$. The problem with these two arguments is of course that most of the time we have no way to guarantee that such assumption is satisfied. As we have 
Esta revista forma parte del acervo de la Biblioteca Jurídica Virtual del Instituto de Investigaciones Jurídicas de la UNAM www.juridicas.unam.mx

http://biblio.juridicas.unam.mx

ANDREA POZAS LOYO

When a law is proposed in the People's assembly, what they are being asked is not whether they accept it or reject it, but whether it conforms to the general will...Therefore when the opinion contrary to my own prevails, it proves nothing more than that I made a mistake and that what I took to be the general will was not....

This presupposes, it is true, that all the characteristics of the general will are still in the majority... ${ }^{31}$

If we could know that all the characteristics of the general will are still in the $\mathrm{X}$ percentage of the population, we would only need to establish $\mathrm{X}$ as the threshold to pass any law, the procedure would be expedient since the threshold would always be met and we would be sure that the outcome is epistemically and morally correct. The only problem would be that in case the required threshold is not the majority we would have a decision-making process that does not comply with the principle of equality by giving different ex post weights to the votes. But in the real world we have to provide general criteria for decision-making processes in face of uncertainty regarding the moral and epistemic status of the decision-makers, knowing that unlike the ideal case our moral, epistemic, and pragmatic preoccupations will not be completely satisfied.

To find those general criteria let us then recur to the distinction between different kinds of decisions. We know that Rousseau considers that the decision to form a social con-

seen, the problem with Waldron's argument is that he considers that we can reasonably assume that this assumption is satisfied most of the time. Neither Rousseau nor Condorcet seemed to have thought so. "In most of the states internal problems are caused by the brutishness and stupidity of the populace, which is first angered by some vexations it cannot support, then secretly brought tighter and roused by cleaver mischief-makers, assuming whatever authority they want to promote", Rousseau, Jean Jacques, Letters from the Mountain, "Ninth Letter". See: Condorcet, Jean Antoine, "Essay on the Application of Mathematics to the Theory of Decision-Making", in Selected Writings(?), Indianapolis, Hacket, 1999.

31 Rousseau, "Of the Social Contract", cit., IV, iv, p. 124, emphasis added. 
Esta revista forma parte del acervo de la Biblioteca Jurídica Virtual del Instituto de Investigaciones Jurídicas de la UNAM www.juridicas.unam.mx

http://biblio.juridicas.unam.mx

SUPERMAJORITARIAN JUSTIFICATION OF MAJORITY RULE

tract needs to be unanimous. The reason for this prescription is that —as we discussed in the ideal case- unanimity is the only decision-making mechanism that guarantees freedom by making subjection to the law voluntary thus creating obligation to a legitimate sovereign. For this reason too, Rousseau prescribes unanimity for the fundamental laws of the social contract. "By the natural right of societies, unanimity has been required for the formation of the body politic and for the fundamental laws that pertain to its existence". 32

Rousseau argues that if the approval of fundamental laws requires unanimity, their change cannot require less. The reason behind this is clear: requiring less than unanimity would enable fundamental laws (i.e. the basic conditions of the social contract) to be transformed against the will of a set of its citizens sacrificing their freedom and substituting right by force. Now given the very strong requirement for transforming these laws and the dangers that over generalizing such rigidity can bring, Rousseau stresses the need for clearly limiting the laws that will be considered fundamental.

It is necessary to weigh and mediate well upon the capital points that will be established as fundamental laws, and only on these points that the form force of the liberum veto will be brought to bear. This is the way the constitution will be made as solid and these laws as irrevocable as they can be: for it is against the nature of the body politic to impose on itself laws

32 Rousseau, "Considerations on the Government of Poland and on Its Planned Reformation", cit., p. 203. To have an idea of what kind of law Rousseau is referring to here it is useful to note that he identifies among the "fundamental laws that pertain to the existence" of Poland the law that established that Poland was made up of three orders, the one that required unanimity for the election of the king and excluded hereditary, the one that affirmed the unity of Poland and finally the one that guaranteed the equality of the members of the community having political prerogatives, Idem. It is noteworthy that this last one can be considered a right, and if so, Rousseau is here explicitly putting a right out of reach of the majority. 
Esta revista forma parte del acervo de la Biblioteca Jurídica Virtual del Instituto de Investigaciones Jurídicas de la UNAM www.juridicas.unam.mx

http://biblio.juridicas.unam.mx

ANDREA POZAS LOYO

that it cannot revoke; but it is neither against nature nor against reason for it not to be capable of revoking these laws except with the same solemnity it put into establishing them. 33

Now, this line of argument enables Rousseau to answer not only the decision-making process that ought to guide the foundational decisions and their change but provides the grounding to defend majority rule for ordinary laws in non-ideal states.

The most problematic feature of majority rule for law-making in case of disagreement is that the minority becomes subject to a law it disagrees with. Now, a state where the expected percentage of votes in agreement is lower than $100 \%$ (i.e. every non-ideal state except the most corrupt) puts its survival at risk by requiring unanimity for every political decision as Rousseau's analysis of the libertum veto clearly shows. Furthermore, using the criterion of urgency Rousseau argues that "the more rapidly the business at hand has to be resolved, the narrower should be the prescribed difference in weighting opinion, in deliberations which have to be concluded straightaway a majority of one would suffice". ${ }^{34}$ However, given the importance of freedom in Rousseau's political thought, the above pragmatic considerations hardly suffice for prescribing majority rule, and thus permitting laws to be passed if face of a minority's disagreement.

What justifies then Rousseau's prescription of majority rule for ordinary law making if we cannot be sure of its virtue and epistemic wisdom? Why do - quoting Rousseau"the votes of the greatest number always bind the rest" in such a world? Rousseau's answer is clear: "this is a consequence of the social contract". ${ }^{35}$

The key to Rousseau argument is the fact that deciding which decision-making procedure ought to be used for ordi-

33 Ibidem, pp. 203-204.

34 Rousseau, "Of the Social Contract", cit., IV, ii, 125.

35 Ibidem, IV, ii, p. 124; Waldron, Jeremy, "Rights of Majorities and Minorities: Rousseau Revisited", Nomos, XXXII, John W. Chapman and Alan Wertheimer (eds.), 1990, p. 63. 
Esta revista forma parte del acervo de la Biblioteca Jurídica Virtual del Instituto de Investigaciones Jurídicas de la UNAM www.juridicas.unam.mx

http://biblio.juridicas.unam.mx

SUPERMAJORITARIAN JUSTIFICATION OF MAJORITY RULE

nary law making is itself a political decision, more precisely a fundamental political decision. Which decision-making procedure will be used for ordinary lawmaking is a decision that defines the nature of the social contract and-as all other fundamental decisions- it ought to be unanimously approved and should require unanimity to be changed. Now, any individual at the foundational moment wants the state she will be part of to be viable. It is here that the previously mentioned pragmatic reasons in favor of majority rule play an important role. Furthermore, the decisionmaking procedure that will guide the ordinary lawmaking is not decided in isolation, but in conjunction with the other fundamental decisions and the decision-making procedure to change them.

Thus establishing majority rule as the procedure for ordinary law-making and unanimity for transforming the terms of the social contract are not two independent decisions but part of a single one: the decision that forms and defines the political society. Majority rule is legitimized because it is the result of a social contract freely agreed on, which can only be a social contact that while feasible has institutions that protect freedom. The minority is obliged to submit to the choice of the majority only because such majority is limited: because it required the minority to establish majority rule for ordinary law-making and all other fundamental laws, and because it still requires it if they want to change them. In Rousseau's own words:

Indeed if there were no prior convention, then unless the election were unanimous, why would the minority be obliged to submit to the choice of the majority, and why would a hundred who want a master have the right to vote on behalf of ten who do not want one? The law of majority rule is itself something established by convention, and presupposes unanimity at least once. ${ }^{36}$

36 Rousseau, "Of the Social Contract", cit., I, vi, 49. 
Esta revista forma parte del acervo de la Biblioteca Jurídica Virtual del Instituto de Investigaciones Jurídicas de la UNAM www.juridicas.unam.mx

http://biblio.juridicas.unam.mx

ANDREA POZAS LOYO

Finally, let us note that between ordinary and fundamental laws there are laws that while not determinant for the nature of the political society are of greater importance than ordinary laws. These laws, Rousseau tells us, should be voted by a supermajority

"...the more important and serious the deliberations are, the more nearly unanimous should be the opinion that prevails...". ${ }^{37}$ To justify this prescription we can apply the same kind of reasoning as above. On the one hand, at the founding moment pragmatic reasons may advise against asking unanimity to pass these laws given the risk of a deadlock. "...[T] he things that merely make up the body of legislation, as for the ones arranged under the title of matters of State, by the vicissitude of things they are subject to unavoidable variations that do not allow them to require unanimity in them". ${ }^{38}$ On the other hand, from a moral perspective given the importance of these laws their legitimacy requires more than a mere majority. In this way we close our interpretation of Rousseau's prescriptions for decision-making procedures.

In sum, this interpretation of Rousseau enables a comprehensive and coherent account of Rousseau's prescriptions for different kinds of law-making, for different type of decisions under different circumstances. Let me know present and argue against an influential alternative interpretation: that of Jeremy Waldron.

\section{WALDRON REVISITS RoussEAU}

Jean Jacques Rousseau is one of the most important advocates of popular sovereignty. Therefore, it is not surprising that it has often been argued that Rousseau considered majority rule as the best decision-making procedure for politics. Jeremy Waldron is one of the most influential voices

37 Ibidem, IV, iii, p. 125.

38 Rousseau, "Considerations on the Government of Poland and on Its Planned Reformation”, cit., p. 204. 
Esta revista forma parte del acervo de la Biblioteca Jurídica Virtual del Instituto de Investigaciones Jurídicas de la UNAM www.juridicas.unam.mx

http://biblio.juridicas.unam.mx

SUPERMAJORITARIAN JUSTIFICATION OF MAJORITY RULE

among the many authors who have defended the majoritarian interpretation of Rousseau. Waldron's support of majority rule as the mark of democratic decision-making has leaded him to severely criticize the legitimacy of any restriction on it. To make his case, he has resorted to Rousseau. The aim of this section is to present a critique to Waldron's interpretation as an important alternative to the interpretation I defend.

Waldron introduces an ideal-typical contrast between two different models of democratic decision-making: the Benthamite and the Rousseaunian. In the former, individual votes represent individual satisfactions, and majority vote-counting approximates a social welfare function with individual satisfactions as its arguments (Waldron 1990: 49). In the Rousseaunian model, in contrast, individual votes express an opinion about what the general will requires, i.e. what conduces to the common good of all society. ${ }^{39}$

Given that democracies make social decisions functions of individual decisions, a theory of democracy is Benthamite to the extent that it takes individual decisions to represent personal satisfactions or interests and Rousseaunian to the extent that it takes individual decisions to represent opinions or beliefs about the general good. 40

Waldron's Rousseaunian argument then proceeds to link majority rule and the general will under the provision that individual votes do express an opinion about what the general will requires. He refers us to Rousseau in this regard.

When a law is proposed in the People's assembly, what they are being asked is not whether they accept it or reject it, but whether it conforms to the general will...Therefore when the opinion contrary to my own prevails, it proves nothing more

39 Waldron, op. cit., p. 50.

40 Ibidem, p. 51. 
Esta revista forma parte del acervo de la Biblioteca Jurídica Virtual del Instituto de Investigaciones Jurídicas de la UNAM www.juridicas.unam.mx

http://biblio.juridicas.unam.mx

ANDREA POZAS LOYO

than that I made a mistake and that what I took to be the general will was not. ${ }^{41}$

Waldron sums up his interpretation in the following way: "Rousseau's settled position appears to have been this: if there is disagreement, and if in spite of that disagreement you can be sure that the citizens are nevertheless addressing the issue of the general good, then, "the votes of the greatest number always bind the rest"'.42 But what are the reasons that ground this conclusion? Rousseau's answer -Waldron tells us - is: "this is a consequence of the social contract". ${ }^{43}$ But Waldron considers this an obscure remark: "I can see nothing in Rousseau's earlier analysis of the social contract to which it would be a reference". ${ }^{44}$ Thus, Waldron resorts to the Condorcetian interpretation of the General Will. 45

The Condorcetian interpretation of the General Will argues that Condorcet's Jury Theorem (1785) shares the basic elements of Rousseau's General Will and that the former can be used to make sense of the latter. ${ }^{46}$ The assumptions of the argument are the following: i) There is a common good and a set of alternatives that more or less share its virtues. Thus the alternatives can be evaluated with respect

41 Rousseau, "Of the Social Contract", cit., IV, ii, p. 124.

42 Waldron, op. cit., p. 63.

43 Rousseau, "Of the Social Contract", cit., IV, ii, p. 124.

44 Waldron, op. cit., p. 63.

45 See: Barry, Brian, Political Argument, London, Routledge, 1965 and Grofman and Scott, op. cit. The following account of the Condorcetian interpretation of the General Will closely follows the very clear account of Grofman and Scott, idem.

46 The basic elements that the Jury Theorem and the General Will share are: 1) There is a common good, 2) citizens are not always accurate in their judgments about what is in the common good and 3) when citizens strive to identify the common good and vote in accordance with their perceptions of it, the vote of the assembly of the people can be taken to be the most reliable means for ascertaining the common good (i.e. it can be taken as very likely to express the General Will). 
Esta revista forma parte del acervo de la Biblioteca Jurídica Virtual del Instituto de Investigaciones Jurídicas de la UNAM www.juridicas.unam.mx

http://biblio.juridicas.unam.mx

SUPERMAJORITARIAN JUSTIFICATION OF MAJORITY RULE

to their consonance with the public interest (the general will) and this evaluation enables rank-ordering alternatives.

(ii) With respect to choice between any pair of alternatives each citizen $i$ has a probability $\mathrm{p}_{\mathrm{i}}>.5$ of choosing that alternative which is more in the public interest (closer to the general will). And (iii) a group of size $\mathrm{N}$ chooses between any two alternatives by means of a majority vote in which each voter is polled about his or her independently reached choice, without any deliberation. ${ }^{47}$ Then, the Jury Theorem mathematically shows that the probability of the group being correct approaches 1 as the group gets larger and the $\mathrm{p}_{\mathrm{i}}$ gets higher. ${ }^{48}$

Once the link between majority rule and the general will has been established, Waldron's Rousseaunian argument faces the criticism of unfeasibility. That is, Waldron needs to make the case that the Rousseaunian model captures to a good extent the way individuals vote. He does so returning to his initial ideal typical dichotomy and by arguing that the Benthamite assumption that votes express individual interests is not the most feasible account of votes. He does so by attacking the Benthamite model and by showing why it is not a more feasible account of the way individuals vote. 49

Among Waldron's criticisms against the Benthamite model there are two that interest us here. The first notes that "if people are egoistic, why expect constitution writers to opt for a system of representative democracy? ...why

47 Waldron introduces deliberation as an element that may enhance the probability that individual votes express the general will and notes that this does not necessarily violate the condition of independence so long as the probability of each individual's reaching a correct decision can be determined independently after the deliberation process and before the votes are taken (Waldron 1990 64).

48 E. g. with a $\mathrm{p}=.51$ a 399-member assembly has a competence of .66 While if $\mathrm{p}=.55$ the same assembly has a competence of .98 . And with a $\mathrm{p}=.7$ a group of only 11 will have a group competence level of above .9

49 Note that this argument is based on the assumption that the dichotomy is exhaustive. 
Esta revista forma parte del acervo de la Biblioteca Jurídica Virtual del Instituto de Investigaciones Jurídicas de la UNAM www.juridicas.unam.mx

http://biblio.juridicas.unam.mx

ANDREA POZAS LOYO

should one expect people to sustain it or to do what is necessary to prevent its corruption?". 50

This point is later developed in more detail with particular emphasis on the feasibility of a Bill of Rights protected by countermajoirtarian mechanisms in a Benthamite world. Waldron notes that since "the decision to institute constraints of right is itself a political decision, we see the possibility and indeed maybe the necessity for the majority, at least on some occasions, to willingly embrace restraints on its collective power". ${ }^{51}$ In sum, the support of the majority, on at least some occasions, is a precondition for both the enactment and the enforcement of constraints of right. And given that in a Benthamite society this would not be possible ${ }^{52}$, then the Benthamite model cannot be accurate on all occasions.

The second criticism that Waldron presents against the Benthamite model criticizes its cognitive assumptions. In particular, he claims that the assumption according to which "each voter is a good judge of his own future self-interest" is unfeasible: "on any account (including Bentham's) people are not reliably prudent". 53

The final move in Waldron's argument is the use of the Rousseaunian model to argue against the majority's constraints regarding the minority's rights. He does so by arguing that in the Rousseaunian model the main argument

50 Waldron, op. cit., p. 48.

51 Ibidem, p. 58.

52 Note that this argument assumes that such restrictions are against the interests of the majority, and identifies the constitutional majority with the constituent majority. For a discussion on the rationality of self binding see Elster Jon, Ulysses and the Sirens: Studies in Rationality and Irrationality, Cambridge, Cambridge University Press, 1979 and "Ulysses Unbound: Constitutions as Constraints" in Ulysses Unbound, Cambridge, Cambridge University Press, 2000.

53 Waldron, op. cit., p. 48. Note that for this argument not to be self-defeating, Waldron needs to assume that "given the circumstances of politics" to know what is required by the general will is easier than to know what one's own future self-interest is. 
Esta revista forma parte del acervo de la Biblioteca Jurídica Virtual del Instituto de Investigaciones Jurídicas de la UNAM www.juridicas.unam.mx

http://biblio.juridicas.unam.mx

SUPERMAJORITARIAN JUSTIFICATION OF MAJORITY RULE

against majority rule regarding minority rights — the fear of majoritarian tyranny - is ungrounded. He argues that the fear of oppression of minorities or individuals in the hands of the majority is only grounded in a Benthamite democracy where the votes are the expression of individual satisfactions and where therefore the outcome of majority vote "means nothing more than the interests of the minority are sacrificed to those of the larger group". ${ }^{44}$ But in Rousseau's model where individual votes represent opinions about the common good this arbitrary sacrifice is not a possible outcome of majority rule. This is the case because individual votes incorporate the "proper balance between the individual and society", individuals' and minority's interests are always properly taken into account. 55 Hence, in a Rousseaunian democracy the fear of majoritarian tyranny is not justified. And since the Roussaunian model captures to a good extent the way individuals vote (in particular regarding important issues such as rights), ${ }^{56}$ the grounding of the constraints on the majority rule is called into question.

Critique to Waldron's Interpretation of Rousseau

Waldron himself identifies a first problematic element in his interpretation. As we have seen, Rousseau claims that the decision of the majority binds the rest as a consequence of the social contract.57 However, Waldron concedes that he finds nothing in Rousseau's treatment of the social contract that could be a reference for Rousseau's claim. ${ }^{58}$ Waldron's interpretation thus leaves this claim unaccounted for. Furthermore, this Rousseaunian claim arguably creates some inconsistencies with the interpreta-

54 Ibidem, p. 64.

55 Ibidem, p. 59.

56 "When they [the people] are given the chance, these are the issues [issues covered by the Bill of Rights] on which voters are least likely to be Bentamite...Voters and their representatives are deeply aware that these are matters they should not be decided purely by consulting their own interests". Ibidem, p. 60.

57 Rousseau, "Of the Social Contract", cit., IV, ii, 124.

58 Waldron, op. cit., p. 63. 
Esta revista forma parte del acervo de la Biblioteca Jurídica Virtual del Instituto de Investigaciones Jurídicas de la UNAM www.juridicas.unam.mx

http://biblio.juridicas.unam.mx

ANDREA POZAS LOYO

tion presented by Waldron, since in the latter the justification for majority rule is uniquely found on its attributes (cognitive and moral) and has nothing to do with the nature of a previous decision, i.e. that of the social contract.

A close reading of Rousseau's scattered claims on decision-making processes lead us to many similar tensions with Waldron's interpretation. For instance, Rousseau's claim that the "...more important and serious the deliberations are, the more nearly unanimous should be the opinion that prevails". 59 Thus, pace Waldron, here Rousseau defends supermajoritarian constraints on the majority for important decisions.

Another instance of conflict is Rousseau's identification of unanimity as the mark of the general will: “...the closer opinions come to unanimity, the more the general will also predominates". ${ }^{60}$ Waldron dismisses this point by noting that Rousseau also says that unanimity prevails in the states where the population has completely lost their freedom. Two things are important to note here:

First, Waldron could dismiss the first claim and the problems it brings for his interpretation, if Rousseau was claiming that unanimity is condition enough for a decision to express the general will. If that was the case then to claim that unanimity prevails in despotic governments would create an inconsistency and thus both claims could be dismissed. However, Rousseau's claim is that unanimity is a necessary condition for a decision to be taken following the general will. In other words, if in a collective decision all the voters decide following the general will then the decision

59 The best translation here as in other texts of Rousseau would be "decisions" not "deliberations" see: Manin, Bernard, Stein, Elly and Mansbridge, Jane, "On legitimacy and Political Deliberation", Political Theory, vol. 15, num. 3.

60 Rousseau, The Social Contract, cit. p. 123. 
Esta revista forma parte del acervo de la Biblioteca Jurídica Virtual del Instituto de Investigaciones Jurídicas de la UNAM www.juridicas.unam.mx

http://biblio.juridicas.unam.mx

SUPERMAJORITARIAN JUSTIFICATION OF MAJORITY RULE

will be unanimous. ${ }^{61}$ Thus, Rousseau's two claims are not inconsistent and Waldron cannot dismiss the former claim.

Second, Rousseau's identification of unanimity as a necessary condition for a general will decision calls into question Waldron's unqualified account of majority rule as a way to discover the general will. To be sure, it is true that Rousseau considers that a decision reached by majority rule can be in accordance with the general will, but this can only be under very specific conditions.

In sum, there are two main problems with Waldron's interpretation of Rousseau. First, it generalizes claims that hold only under specific circumstances and for specific decisions, dismissing or ignoring the arguments presented in favor of other decision-making processes. Hence, Waldron delivers us a partial and thus distorted view on Rousseau's position regarding decision-making mechanisms. Furthermore, this partial view is a malady not only found in Waldron's interpretation of Rousseau but -as I will argue in the last part of the paper- it is also present in much of the contemporary approach to the debate on decision-making processes.

Second, as we have seen, Waldron's interpretation is inconsistent with other statements made by Rousseau. In the first part of this paper I presented an interpretation that delivers a consistent account of Rousseau's view on decision-making procedures. It is noteworthy that Rousseau himself seems to have thought that his views on this issue were consistent as he refers the reader of the Government of Poland to the Social Contract in order not to repeat himself

61 A major difference between Waldron and Rousseau is that the latter considers that disagreement in political questions springs from self-interest (amour propre) while the former does not. “... long debates, dissensions, disturbances, signal the ascendancy of particular interests and the decline of the State". Rousseau, "Of the Social Contract", cit., p. 123. 
Esta revista forma parte del acervo de la Biblioteca Jurídica Virtual del Instituto de Investigaciones Jurídicas de la UNAM www.juridicas.unam.mx

http://biblio.juridicas.unam.mx

ANDREA POZAS LOYO

regarding the "unproblematic" issue of how votes are to be tallied. 62

\section{CONCLUSION}

This paper has provided an interpretation that gives a coherent and complete account of Rousseau's prescriptions for decision-making procedures in law-making. A framework was presented that enables us to understand why unanimity is prescribed for the ideal state, the formation of the social contract and the making and changing of fundamental laws in non-ideal states, while majority rule is prescribed for ordinary law making and important laws require supermajorities proportional to their importance once the state has begun its decay. Furthermore, unlike previous interpretations (e.g. Waldron 1990, Weirich 1986, and Grofman and Scott L. 1988) our interpretation gives a comprehensive account of Rousseau's prescriptions for different kinds of law-making, and of the relations among them. In particular, it gives account of the puzzling Rousseuanian remark that grounds the legitimacy of majority rule in the social contract.

To finalize, I would like to briefly return to the contemporary debate on decision-making procedures for law-making and ask in what way our discussion on Rousseau can contribute to it.

I believe that the most important insight in Rousseau's normative discussion on decision-making procedures for lawmaking is the least discussed. Some of Rousseau's arguments have been extensively discussed in isolation, in particular —as we have seen- his epistemic argument for majority rule. However, this argument has strong assumptions regarding the epistemic status of decision-makers and thus its applicability requires strong empirical evidence showing

62 See: Rousseau, "Considerations on the Government of Poland and on Its Planned Reformation", cit., p. 189, he makes several more references to the Social Contract e.g. Ibidem., pp. 190 and 236. 
Esta revista forma parte del acervo de la Biblioteca Jurídica Virtual del Instituto de Investigaciones Jurídicas de la UNAM www.juridicas.unam.mx

http://biblio.juridicas.unam.mx

SUPERMAJORITARIAN JUSTIFICATION OF MAJORITY RULE

that the assumption is satisfied, which is not a possibility in most of the cases including that of law-making in contemporary democracies. I believe that the focus on isolated claims made by Rousseau and not on his overall approach are not coincidental. On the contrary, I think they signal the way the contemporary debate approaches the question, focusing on the desirability of a decision-making procedure in abstract, obviating the conditions of its applications.

Therefore, I believe that Rousseau's most important insight for the contemporary debate can be found in his claim that the justification for majority rule is a consequence of the social contract. ${ }^{63}$ In particular, in the fact that the reasoning to adopt a decision-making process for political decisions under non-ideal circumstances cannot be self-contained, but needs to be related to a broader institutional scheme that considers the moral, epistemic and pragmatic drawbacks of the decision-making process in the specific political context given our ineludible uncertainty regarding the epistemic and moral status of decision-makers.

\section{REFERENCES}

ARISTOTLE, Politics, translated by H Rackham, Loeb Classical Library Cambridge, Mas., Harvard University Press, 1977.

BARRY, Brian, Political Argument, London, Routledge, 1965.

CoHen, Joshua, Rousseau: A Free Community of Equals, Oxford, Oxford University Press, 2010.

63 Rousseau, "Of the Social Contract", cit., IV, ii, p. 124. The idea that an analytical approach to Rousseau is helpful for understanding contemporary political and legal problems is present in several important texts of philosophy see for instance: Cohen, Joshua, Rousseau: A Free Community of Equals, Oxford, Oxford University Press, 2010; Putterman, Ethan, "Realism and Reform in Rousseau's Constitutional Projects for Poland and Corsica”, Political Studies, vol. 49, 2001; Rawls, op. cit.; Stilz, Anna Liberal Loyalty: Freedom, Obligation, and the State, Princeton, NJ, Princeton University Press, 2009. 
Esta revista forma parte del acervo de la Biblioteca Jurídica Virtual del Instituto de Investigaciones Jurídicas de la UNAM www.juridicas.unam.mx

http://biblio.juridicas.unam.mx

ANDREA POZAS LOYO

CONDORCET, Jean Antoine, "Essay on the Application of Mathematics to the Theory of Decision-Making", Selected Writings, Indianapolis, Hacket, 1999.

ELSTER, Jon, Ulysses and the Sirens: Studies in Rationality and Irrationality, Cambridge, Cambridge University Press, 1979.

ElSTER, Jon, "Ulysses Unbound: Constitutions as Constraints", Ulysses Unbound, Cambridge, Cambridge University Press, 2000.

GROFMAN, Bernard and FELD, Scott L., "Rousseau's General Will: A Condorcetian Perspective", American Political Science Review, vol. 82, num. 2, 1988.

HABERMAS, Jurgen, "Constitutional Democracy: A Paradoxical Union of Contradictory Principles?", Political Theory, vol. 29, num. 6, December, 2001.

Holmes, Stephen, "Constitutionalism", in LIPSET, Seymour Martin (ed.), The Encyclopedia of Democracy, Washington, Congressional Quarterly, 1995.

Hume, David, Enquiries Concerning Human Understanding and Concerning the Principles of Morals, Oxford, Clarendon Press, 1975.

KELSEN, Hans, "On the Essence and Value of Democracy", in JACOBSON, Arthur and ScHLInK, Bernhard (eds.), Weimar. A Jurisprudence of Crisis, Berkeley, University of California Press, 2002.

MANIN, Bernard et al., "On Legitimacy and Political Deliberation", Political Theory, vol. 15, num. 3.

Miller, J., Rousseau: Dreamer of Democracy, New Haven, CT, Yale University Press, 1984.

PuTTERMAN, Ethan, "Realism and Reform in Rousseau's Constitutional Projects for Poland and Corsica", Political Studies, vol. 49, 2001. 
Esta revista forma parte del acervo de la Biblioteca Jurídica Virtual del Instituto de Investigaciones Jurídicas de la UNAM www.juridicas.unam.mx

http://biblio.juridicas.unam.mx

SUPERMAJORITARIAN JUSTIFICATION OF MAJORITY RULE

PutTERman, Ethan, Rousseau, Law and the Sovereignty of the People, Cambridge, Cambridge University Press, 2010.

RAWLS, John, A Theory of Justice, Cambridge, Harvard University Press, 1999.

RAWLS, John, Lectures on the History of Political Philosophy, in FreEman, Samuel (ed.), Cambridge, MA, Belknap Press of Harvard University, 2007.

Rousseau, Jean Jacques, "Of the Social Contract", in GoUREVITCH, Victor (ed. and trans.), The Social Contract and other Later Political Writings, Cambridge, Cambridge University Press, 1997.

Rousseau, Jean Jacques, "Discourse on Political Economy", in CRESS, Donald A. (trans.), The Basic Political Writings, Indianapolis, Hackett Publishing Company, 1987.

Rousseau, Jean Jacques, Émile or on Education, Allan Bloom (trans.), New York, Basic Books, 1979.

RousseaU, Jean Jacques, "Considerations on the Government of Poland and on Its Planned Reformation", in KELly, Christopher (ed.), Collected Writings of Rousseau, vol. II, Lebanon, NH, University Press on New England, 2005.

Rousseau, Jean Jacques, Letters from the Mountain "Ninth Letter".

PASQUINO, Pasquale, Unpublished Manuscript, 2006.

PUTTERMAN, Ethan, "Realism and Reform in Rousseau's Constitutional Projects for Poland and Corsica", Political Studies, vol. 49, 2001.

PutTerman, Ethan, Rousseau, Law and the Sovereignty of the People, Cambridge, Cambridge University Press, 2010. 
Esta revista forma parte del acervo de la Biblioteca Jurídica Virtual del Instituto de Investigaciones Jurídicas de la UNAM

SchWARTZBERG, Melissa, "Voting the General Will: Rousseau on Decision Rules", Political Theory, vol. 36, num. 3, 2008.

SKHLAR, Judith N., Men and Citizens: A Study of Rousseau's Social Theory, New York, Cambridge University Press, 1985.

STILZ, Anna, Liberal Loyalty: Freedom, Obligation, and the State, Princeton, NJ, Princeton University Press, 2009.

WALDRON, Jeremy, "Rights of Majorities and Minorities: Rousseau Revisited", Nomos, vol. XXXII, John W. Chapman and Alan Wertheimer (eds.), 1990.

WEIRICH, Paul, "Rousseau on Proportional Majority Rule", Philosophy and Phenomenological Research, vol. XLVII, num. I, September 1986. 